DOI: $10.1590 / 1809-6891 v 19 \mathrm{e}-49678$

RECURSOS PESQUEIROS E ENGENHARIA DE PESCA

\title{
EPIZOOTIOLOGY OF Perkinsus sp. INFESTING Crassostrea rhizophorae FROM THE SEMI-ARID REGION, BRAZIL
}

\section{EPIZOOTIOLOGIA DE Perkinsus sp. INFESTANDO Crassostrea rhizophorae DA REGIÃO SEMI-ÁRIDA, BRASIL}

\author{
Cláudio Giovanio da Silva ${ }^{1^{*}}$ \\ Naibe Cristina de Figueiredo ${ }^{1}$ \\ José Ticiano Arruda Ximenes de Lima $^{1}$ \\ Inês Xavier Martins ${ }^{1}$ \\ ${ }^{1}$ Universidade Federal Rural do Semi-Árido, Mossoró, RN, Brazil. \\ *Corresponding author - giovaniosl@bol.com.br
}

\begin{abstract}
The coast of the semi-arid region of Brazil is known for the presence of large estuaries inhabited by numerous species of edible bivalve mollusks. The oyster $C$. rhizophorae is naturally found in estuarine environments along the Brazilian coast, fixed on substrates, mainly in the roots of mangroves. Protozoa of the genus Perkinsus are important parasites of marine bivalves, sometimes causing significant pathological damage throughout the world. This study reports the occurrence of parasites Perkinsus sp. in mangrove oysters from Porto de Mangue estuary (Rio Grande do Norte state) and Icapuí estuary (Ceará state), two estuaries of the semi-arid region of Brazil. In Porto do Mangue estuary, oysters were collected in December 2016, January and February 2017. In Icapuí estuary, oyster sampling occurred in September, October and November 2017. Two fragments of the gills were incubated in Ray's Fluid Thioglycollate Medium - RFTM. The ecological and parasitological parameters were calculated. Five of the ninety oysters collected in Porto do Mangue estuary were parasitized, which corresponded to a mean prevalence of $5.6 \%$, and in Icapuí estuary 18 of the 120 oysters collected were parasitized, which corresponded to a mean prevalence of $15.0 \%$. The intensity of infection by Perkinsus sp. ranged from very mild to mild.
\end{abstract}

Keywords: mangroves; oyster; perkinsiosis; RFTM.

\section{Resumo}

A costa da região semi-árida do Brasil é conhecida pela presença de grandes estuários habitados por numerosas espécies de moluscos bivalves comestíveis. A ostra Crassostrea rhizophorae é encontrada naturalmente em ambientes estuarinos ao longo da costa brasileira, fixados em substratos, principalmente nas raízes dos manguezais. Os protozoários do gênero Perkinsus são parasitos importantes de bivalves marinhos, às vezes causando danos patológicos significativos em todo o mundo. Este estudo relata a ocorrência de parasitos Perkinsus sp. nas ostras de mangue do estuário de Porto do Mangue (estado do Rio Grande do Norte) e estuário de Icapuí (estado do Ceara), duas regiões do semiárido do Brasil. No estuário de Porto do Mangue as amostragens de ostras ocorreram nos meses de dezembro de 2016, janeiro e fevereiro de 2017. No estuário de Icapuí as amostragens de ostras ocorreram nos meses de setembro, outubro e novembro de 2017. Dois fragmentos branquiais foram incubados em Ray's Fluid Thioglycollate Medium (RFTM). Os parâmetros ecológicos e 
parasitários foram calculados. Cinco das noventas ostras coletadas no estuário de Porto do Mangue estavam parasitadas, que correspondeu a uma prevalência média de 5,6\%. No estuário de Icapuí estavam parasitadas dezoito das cento e vinte ostras, correspondendo a uma prevalência média de 15,0\%. As intensidades de infecção por Perkinsus sp. variaram de muito leve a leve nas duas localidades.

Palavras-chave: Manguezais; Ostra; Perkinsose; RFTM.

Received on: October 6th, 2017.

Accepted on: January 19th, 2018.

\section{Introduction}

The coast of the semi-arid region of Brazil is known for the presence of large estuaries inhabited by numerous species of edible bivalve mollusks due to high primary productivity in seawater and favorable climatic and geographic conditions in these environments ${ }^{(1)}$. Brazil is the second largest country in extension of mangrove areas, only lagging behind Indonesia( ${ }^{(2)}$.

Two mangrove oyster species (Crassostrea rhizophorae and C. gasar) inhabit the estuaries of the Northeast region of Brazil ${ }^{(3)}$. The oyster $C$. rhizophorae is naturally found in estuarine environments along the Brazilian coast, fixed on substrates, mainly in the roots of mangroves ${ }^{(4)}$. Mangrove oysters are produced using artisanal techniques, which include the sampling of naturally settled spats at different places in an estuary ${ }^{(3)}$.

The production of oysters is threatened by the emergence of epizootic diseases, mainly caused by bacteria and protozoa ${ }^{(1)}$. The bivalve mollusks may be affected by many parasites that can cause diseases and contribute to reducing natural, but mainly cultivated, populations ${ }^{(5)}$.

Studies on diseases in mollusks are important because some pathogens can affect and can cause massive mortality ${ }^{(1)}$. Protozoa of the genus Perkinsus are important parasites of marine bivalves, sometimes causing significant pathological damage throughout the world ${ }^{(6,7)}$. Mortality events associated with this disease affect the dynamics of oysters populations and the structure and ecological function of beds of oysters, strongly modulated by environmental conditions ${ }^{(8)}$.

The infection caused by these protozoa is known as perkinsiosis or also as "Dermo", in reference to the first denomination of this protozoan regarding the oyster $C$. virginica in the USA ${ }^{(9)}$. Since the emergence of this genus, seven species of Perkinsus were confirmed and described as pathogens of marine snails all over the world ${ }^{(10)}$ : Perkinsus marinus, $P$. olseni, $P$. guqwadi, $P$. chesapeaki, $P$. mediterraneus, $P$. honshuensis, and $P$. beihaiensis ${ }^{(11)}$. Among these species, $P$. marinus and $P$. olseni require mandatory notifications to the World Organization for Animal Health, due to the risk that they represent for mollusk populations ${ }^{(12)}$.

In Brazil, four different species of Perkinsus have already been reported in mollusks: P. chesapeaki, P. Beihaiensis, P. Marinus, and P. olseni. They infect three species of hosts: Crassostrea rhizophorae, C. gasar, and Anomalocardia brasiliana ${ }^{(13-15)}$.

The present article presents a study of the parasites Perkinsus sp. found in the mangrove oysters Crassostrea rhizophorae from Porto do Mangue estuary (Rio Grande do Norte state) and Icapuí estuary (Ceara state), two regions of the Brazilian semi-arid. 


\section{Material and Methods}

Located in the semi-arid of Brazil, the coastal region of Ceara and Rio Grande do Norte presents hot humid tropical climate, with rains in the summer (December to March) and dry conditions during autumn, winter, and spring (April to November), and an annual mean air temperature of $32{ }^{\circ} \mathrm{C}$. The city of Porto do Mangue, where the collections were held, comprises an area of approximately $332 \mathrm{~km}^{2(11)}$. The city of Icapuí is located in the extreme east coast of Ceara state, in the sub-basin of the region of Baixo Jaguaribe, with an area of $423 \mathrm{~km}^{2(16)}$. The two estuaries are covered by mangrove vegetation.

The first (Crassostrea rhizophorae) oyster samplings took place in Porto do Mangue estuary, in December $(n=10)$ of 2016, January $(n=40)$ and February $(n=40)$ of 2017 , being carried out a preliminary assessment of the presence of Perkinsus sp. in Rio Grande do Norte state. Subsequently, oysters from Icapuí estuary in Ceara state were collected in September $(n=40)$, October $(n=40)$, and November $(n=40)$ of 2017 (Figure 1).

Oysters were collected manually and directly from the roots of the Rhizophora mangle (red mangrove) at low tide, and were transported alive in isothermal boxes to the laboratory facilities. Water temperature and salinity of the sampling area were measured.

Shells were measured ( \pm standard deviation) in millimeters $(\mathrm{mm})$. After that, they were kept in 20liter aquariums in closed system with sea water and aeration for over $24 \mathrm{~h}$ before processing for Perkinsus parasites isolation.

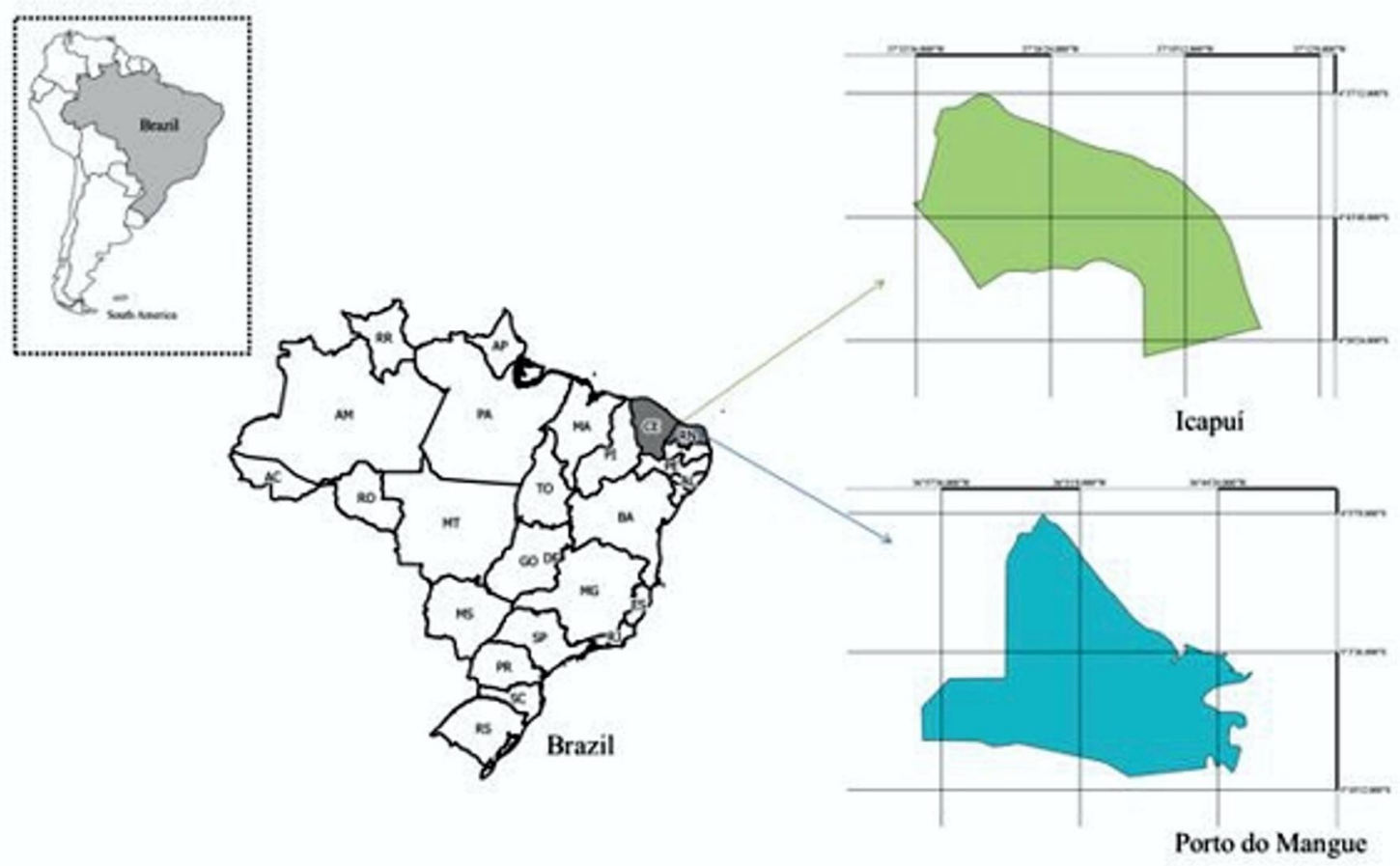

Figure 1: Brazil Map highlighting Ceara state and Rio Grande do Norte state, indicating the collection points at Porto do Mangue estuary and Icapuí estuary.

Pathological changes in the shell and body (mantle, gills, gonads, and digestive gland) were also observed. All animals collected in the estuary were processed in Ray's Fluid Thioglycollate Medium 
$-\operatorname{RFTM}^{(17)}$.

Fragments of the gills were incubated in RFTM during seven days in the absence of light at room temperature. After the incubation period, the samples were prepared for microscopic analysis by cutting the fragments and macerating the tissue on a slide and examining the obtained preparations by optical microscopy to verify the presence of parasites of the genus Perkinsus.

The ecological and parasitological parameters, as the prevalence of pathogen (percentage of infected hosts, $\mathrm{P} \%$ ) and intensity of infection, were calculated according to Bush et al. ${ }^{(18)}$ and Silva et al. ${ }^{(11)}$.

The scale of intensity of infection by Perkinsus sp. in the tissues of mangrove oysters (C. rhizophorae) was obtained in accordance with Sabry et al. ${ }^{(19)}$ : without infection (without cells observed in the whole preparation); very mild infection (up to 10 cells observed in the whole preparation); mild infection (11 to 100 cells observed in the whole preparation); moderate infection (at least 40 cells observed in each of the 10 fields of the microscope (40x) scattered over the tissue); and heavy infection (more than 40 cells observed in each of the 10 fields of the microscope (40x) scattered over the tissue).

\section{Results}

Mean size $( \pm \mathrm{SD})$ of oysters collected in Porto do Mangue estuary was $46.8 \pm 4.4 \mathrm{~mm}$ and in Icapuí estuary, $47.0 \pm 3.9 \mathrm{~mm}$. Water temperature and salinity observed at the time of collection were $28^{\circ} \mathrm{C}$ and $37 \%$ in Porto do Mangue estuary, respectively, and $27^{\circ} \mathrm{C}$ and $35 \%$ in Icapuí estuary, respectively.

Five (n5) of the ninety (n90) oysters collected in Porto do Mangue estuary in December/2016, January and February 2017 were parasitized, which corresponded to a mean prevalence of perkinsiosis of $5.6 \%$. The intensity of infection by Perkinsus ranged from very mild $(\mathrm{n}=3)$ to mild $(\mathrm{n}=2)$ in the months in study. December was the only month where values of prevalence and intensity of infection were not recorded because this month there were fewer individuals collected (Table 1). In Icapuí estuary, 18 (n18) of the 120 (n120) oysters collected were parasitized between the months of September, October, and November 2017, corresponding to a mean prevalence of $15.0 \%$, and intensity of infection by Perkinsus ranged from very mild $(n=13)$ to mild $(n=5)$.

Table 1. Monthly indexes of prevalence ( $\%$ \%), intensity of infection by Perkinsus sp., and mean size ( \pm standard deviation) of oysters $(\mathrm{N}-$ number of oysters collected; $\mathrm{PM}-$ Porto do Mangue; ICP - Icapui)

\begin{tabular}{llllll}
\hline Months of collection & $\mathbf{N}$ & $\begin{array}{l}\text { Size } \\
(\mathbf{m m})\end{array}$ & $\mathbf{P \%}$ & Intensity of infection & Locality \\
\hline December & 10 & $44.2 \pm 3.5$ & 0.00 & without & PM \\
January & 40 & $47.4 \pm 5.9$ & 7.50 & very mild and mild & PM \\
February & 40 & $47.5 \pm 3.0$ & 5.00 & very mild & PM \\
September & 40 & $48.1 \pm 4.3$ & 10.0 & very mild & ICP \\
October & 40 & $46.3 \pm 3.7$ & 22.5 & very mild and mild & ICP \\
November & 40 & $46.6 \pm 3.4$ & 12.5 & very mild and mild & ICP \\
\hline
\end{tabular}

The protozoan Perkinsus sp., belonging to the class Perkinsea, family Perkinsidae and genus 
Perkinsus $^{(20)}$ after branchial process in RFTM, were identified by observation in optical microscope. The cells of the parasite were spherical and stained in black, and they presented a diameter from $28.23 \mu \mathrm{m}$ to $51.30 \mu \mathrm{m}$ (in both areas), typical characteristic of this species (Figure 2).

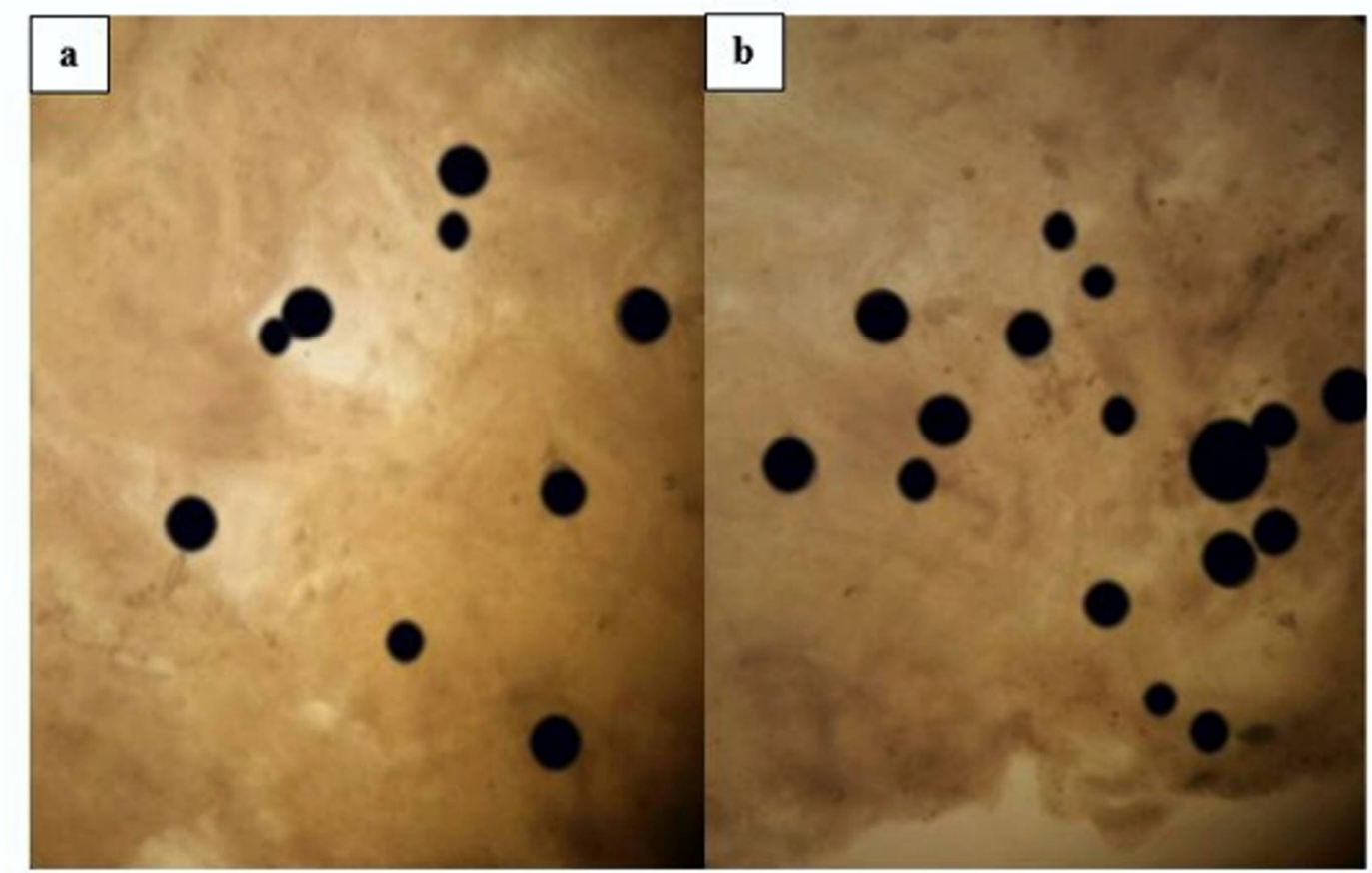

Figure 2. Hypnospores from Perkinsus sp. infecting the gills of Crassostrea rhizophorae after incubation in Ray's fluid thioglycollate medium (RFTM). Perkinsus sp. in C. rhizophorae (a) Porto do Mangue estuary, Rio Grande do Norte and (b) Icapui estuary, Ceara.

\section{Discussion}

This is the first report of the occurrence of Perkinsus sp. parasitizing mangrove oysters (Crassostrea rhizophorae) in Porto do Mangue estuary (Rio Grande do Norte) and Icapuí estuary (Ceará). The preparation in RFTM revealed the presence of hypnospores of Perkinsus sp. infecting the gills of $C$. rhizophorae with very mild and mild infection intensity levels.

According to Boehs et al. ${ }^{(9)}$, protozoa of the genus Perkinsus affecting bivalve mollusks in various regions of the world and can cause major economic losses depending on the species and the affected host, requiring further studies to monitor this epizootiology.

The prevalence of infection by Perkinsus was considerably lower than that found in studies with mollusks from other regions of Brazil. Sabry et al. ${ }^{(19,21)}$ found a prevalence of 5.78 and $23.33 \%$ in $C$. rhizophorae in the estuary of Pacoti on the coast of Ceara state. On the coast of Bahia state, the high prevalence of Perkinsus sp. in C. rhizophorae has reached $63 \%{ }^{(22)}$. Queiroga et al. ${ }^{(15,23)}$ recorded high (93.3\%) and moderate (48.9\%) prevalence in C. gasar in the estuary of the Mamanguape River (Paraíba state). Silva et al. ${ }^{(13)}$ verified $100 \%$ (high) prevalence of $P$. marinus infecting C. rhizophorae in Paraiba River (Paraiba state). Ferreira et al. ${ }^{(14)}$, in the estuary of Timonha river (Ceara state), obtained a mean prevalence of $14.7 \%$ of Perkinsus sp. infesting Anomalocardia brasiliana. Scardua et al. ${ }^{(3)}$, in São Francisco river, Sergipe state, obtained a moderate prevalence of $47.8 \%$ in Crassostrea spp.. Silva et al. ${ }^{(1)}$ studied the presence of Perkinsus on a farm in Rio Grande do Norte state and 
obtained 17 to $75 \%$ prevalence. Silva et al. ${ }^{(24)}$ was also detected in P. marinus in C. gasar from Sergipe state; the mean prevalence was higher in cultured oysters $(56 \%)$ than in wild oysters $(35 \%)$.

The prevalence in this study was higher than that found by Neto et al. ${ }^{(12)}$, who observed the prevalence of $P$. chesapeaki (2.6\%) and P. beihaiensis (3.3\%) infesting C. rhizophorae in the estuary of Jaguaribe river (Ceara state).

Perkinsus parasite was originally described as a pathogen of abalone in South Australia and the first record of Perkinsus in South America was made in Uruguay ${ }^{(25)}$.

According to Silva et al. ${ }^{(24)}$, the dynamics of infection by P. marinus and P. olseni in C. gasar $(=C$. brasiliana) may have seasonal variations in tropical climate and be associated with cultural practices. This variation of infection may also be associated with $C$. rhizophorae, which would explain the low prevalence in the study.

In the semi-arid region of Brazil, the pattern of infection by Perkinsus sp. in oysters seems to be associated with salinity, i.e. the prevalence decreases at low salinities, which usually occurs in the rainy season ${ }^{(1,15,22,24)}$. Accordingly, the prevalence on this study was higher in the Icapuí estuary in the months characterized by drought, and low in Porto do Mangue estuary during rainy months.

Molecular biology analysis to confirm phylogenetic and provide a molecular diagnosis to identify species of Perkinsus in mollusks from Rio Grande do Norte and Ceara are still necessary.

According to Sabry et al. (21), the effects of perkinsosis on the host and the natural populations of oysters from the northeast region should be evaluated. It is imperative to introduce strategies to restrict the spread of the disease.

Ferreira et al. ${ }^{(14)}$ states that, due to the large differences observed in the prevalence of Perkinsus sp. in mollusks of the entire Brazilian coast, further studies are needed to better understand the dynamics of this parasitic pathogen infection in mangrove oysters.

In conclusion, this is the first study that identifies Perkinsus sp. naturally infecting the mangrove oysters (Crassostrea rhizophorae) in Porto do Mangue estuary (Rio Grande do Norte state) and Icapuí estuary (Ceara state) located in the semi-arid region of Brazil with intensity levels of infection varying from very mild to mild.

\section{Ethical Approval}

All procedures performed in this study involving animals were in accordance with the ethical standards of the institution.

\section{Acknowledgements}

We thank CNPq (Conselho Nacional de Desenvolvimento Científico e Tecnológico) and CAPES (Coordenação de Aperfeiçoamento de Pessoal de Nível Superior) for the research grants and the financial support given to post-graduate and undergraduate programs and to UFERSA for the technical and scientific support. In addition, we thank Professor Marcia Avelino Coelho for the audit provided to the study. 


\section{References}

1. Silva PMD, Costa CP, Araújo JPBD, Queiroga FR, Wainberg AA. Epizootiology of Perkinsus sp. in Crassostrea gasar oysters in polyculture with shrimps in northeastern Brazil. Revista Brasileira de Parasitologia Veterinária. 2016;25(1): 37-45.

2. Filho PWMS. Costa de Manguezais de Macromare da Amazonia: Cenarios Morfologicos, Mapeamento e Quantificacao de Areas Usando Dados de Sensores Remotos. Rev Bras Geofisica. 2005;23:427-35.

3. Scardua MP, Vianna RT, Duarte SS, Farias ND, Correia MLD, Santos HTAD, Silva PMD. Growth, mortality and susceptibility of oyster Crassostrea spp. to Perkinsus spp. infection during on growing in northeast Brazil. Revista Brasileira de Parasitologia Veterinária, 2017;26(4):401-410. Available from: dx.doi.org/10.1590/S1984-29612017061

4. Guimarães IM, Antonio ÍG, Peixoto S, Olivera A. Salinity influence on the survival of mangrove oyster, Crassostrea rhizophorae. Arq Ciências do Mar. 2008;41:118-22.

5. Sabry RC, Magalhães ARM. Parasitas em ostras de cultivo (Crassostrea rhizophorae e Crassostrea gigas) da Ponta do Sambaqui, Florianópolis, SC. Arq Bras Med Vet Zootec. 2005;57:194-203.

6. Ramilo A, Carrasco N, Reece KS, Valencia JM, Grau A, Aceituno P, et al. Update of information on perkinsosis in NW Mediterranean coast: Identification of Perkinsus spp. (Protista) in new locations and hosts. J Invertebr Pathol. 2015;125:37-41. Available from: dx.doi.org/10.1016/j.jip.2014.12.008

7. Elandaloussi LM, Carrasco N, Roque A, Andree K, Furones MD. First record of Perkinsus olseni, a protozoan parasite infecting the commercial clam Ruditapes decussatus in Spanish Mediterranean waters. J Invertebr Pathol. 2009;100:50-3. Available from: dx.doi.org/10.1016/j.jip.2008.09.004

8. Powell EN. What is going on with Perkinsus marinus in the Gulf of Mexico? Estuaries and Coasts. 2017;40(1):105. Available from: dx.doi.org/10.1007/s12237-016-0128-7

9. Pinto TR, Boehs G, Blohem WF, Luz MDSA, Costa H. Detection of Perkinsus marinus in the oyster Crassostrea rhizophorae in southern Bahia by proteomic analysis. Braz. j. vet. res. anim. sci, 2016;53(4): 0104. Available from: dx.doi.org/10.11606/issn.1678-4456.bjvras.2016.104524

10. Ramilo A, Pintado J, Villalba A, Abollo E. Perkinsus olseni and P. chesapeaki detected in a survey of perkinsosis of various clam species in Galicia (NW Spain) using PCR-DGGE as a screening tool. J Invertebr Pathol. 2016;133: 50-8. Available from: dx.doi.org/10.1016/j.jip.2015.11.012

11. Silva CG, Figueiredo NC, Martins IX, Lima JTAX. Protozoan Parasite Perkinsus sp. Infecting Crassostrea rhizophorae From the Coast of Rio Grande do Norte (Northeast of Brazil). J Aquac Mar Biol. 2017;6(5):166. Available from: 10.15406/jamb.2017.06.00166

12. Neto MPD, Gesteira TCV, Sabry RC, Feijó RG, Forte JM, Boehs G, et al. First record of Perkinsus chesapeaki infecting Crassostrea rhizophorae in South America. J Invertebr Pathol. 2016;141:53-6.

13. Silva PM da, Vianna RT, Guertler C, Ferreira LP, Santana LN, Fernández-Boo S, et al. First report of the protozoan parasite Perkinsus marinus in South America, infecting mangrove oysters Crassostrea rhizophorae from the Paraíba River (NE, Brazil). J Invertebr Pathol. 2013;113(1): 96-103. Available from: dx.doi.org/10.1016/j.jip.2013.02.002

14. Ferreira LP, Sabry RC, Silva PM da, Gesteira TCV, Romão L de S, Paz MP, et al. First report of Perkinsus beihaiensis in wild clams Anomalocardia brasiliana (Bivalvia: Veneridae) in Brazil. Exp Parasitol. 2015;150: 67-70. Available from: dx.doi.org/10.1016/j.exppara.2014.07.012

15. Queiroga FR, Vianna RT, Vieira CB, Farias ND, Silva PM da. Parasites infecting the cultured oyster Crassostrea gasar (Adanson, 1757) in Northeast Brazil. Parasitology. 2015;142: 756-66. Available from: 
dx.doi.org/10.1017/S0031182014001863

16. IPECE. Instituto de Pesquisa e Estratégia Econômica do Ceará. Perfil Básico dos Município. FortalezaCE, 2010.

17. Ray SM. A review of the culture method of detecting Dermocystidium marinum with suggested modifications and precautions. Proc Natl Shellfish Assoc. 1966;54: 55-69.

18. Bush AO, Lafferty KD, Lotz JM, Shostak AW. Parasitology Meets Ecology on its own Terms: Margolis et al. Revised. J Parasitol. 1997;83(4): 575-83.

19. Sabry RC, Rosa RD, Magalhães ARM, Barracco MA, Gesteira TCV, Silva PM da. First report of Perkinsus sp. infecting mangrove oysters Crassostrea rhizophorae from the Brazilian coast. Dis Aquat Organ. 2009;88: 13-23.

20. Levine ND. Perkinsus gen. n. and other new taxa in the protozoan phylum Apicomplexa. J Parasitol. 1978; 64:549.

21. Sabry RC, Gesteira TCV, Magalhães ARM, Barracco MA, Guertler C, Ferreira LP, et al. Parasitological survey of mangrove oyster, Crassostrea rhizophorae, in the Pacoti River Estuary, Ceará State, Brazil. J Invertebr Pathol. 2013;112(1): 24-32. Available from: dx.doi.org/10.1016/j.jip.2012.10.004

22. Brandão RP, Boehs G, Sabry RC, Ceuta LO, Luz M dos SA, Queiroga FR, et al. Perkinsus sp. infecting oyster Crassostrea rhizophorae (Guilding, 1828) on the coast of Bahia, Brazil. J Invertebr Pathol. 2013;112: $138-41$.

23. Queiroga FR, Marques-santos LF, Hégaret H, Soudant P, Farias ND, Schlindwein AD, et al. Immunological responses of the mangrove oysters Crassostrea gasar naturally infected by Perkinsus sp. in the Mamanguape Estuary, Paraíba state. Fish Shellfish Immunol. 2013; 1-9. Available from: dx.doi.org/10.1016/j.fsi.2013.04.034

24. Silva PM da, Scardua MP, Vianna RT, Mendonça RC, Vieira CB, Dungan CF, et al. Two Perkinsus spp. infect Crassostrea gasar oysters from cultured and wild populations of the Rio São Francisco estuary, Sergipe, northeastern Brazil. J Invertebr Pathol. 2014;119: 62-71. Available from: dx.doi.org/10.1016/j.jip.2014.04.005

25. Reece KS, Scott GP, Dang C, Dungan CF. A Novel Monoclonal Perkinsus chesapeaki In Vitro Isolate from an Australian Cockle, Anadara trapezia. Journal of Invertebrate Pathology. 2017;148: 86-93. 